Leopold Ruzicka, Department of Organie Chemistry, Institute of Technology, Zurich.

\section{Presentation of Medal and other Awards}

At the same meeting, the following medai and other awards were presented:

Daniel Giraud Elliot Gold Medal and Certificate (£warded annually to the author of an outstanding paper, essay or other work on some branch of zoology or palæontology), to Prof. Malcolm R. Irwin of the University of Wisconsin, for his work "Immunogenetic Studies of Species Relationships in Columbidae" (J. Gen.) (for 1938); Prof. John H. Northrop, Rockefeller Institute for Medical Research, Princeton, New Jersey, for his work "Crystalline Enzymes : the Chemistry of Pepsin, Trypsin and Bacteriophage" (Jessup Lectures, Columbia University Press) (for 1939); Prof. William B. Scott of Princeton University, for his work "The Mammalian Fauna of the White River Oligocene. Part IV. Artiodactyia" (Trans. Amer. Phil. Soc.) (for 1940).

Mary Clark Thompson Gold Medal (awarded annually for the most important services during the period in geology and palæontology), to Prof. Edward W. Berry of Johns Hopkins University, for outstanding contributions to knowledge of the Mesozoic and Cenozoic floras of North, Central and South America, and the Antilles, in their relations to stratigraphy, the ecology and geographic distribution of past floras, and the evolution of the different groups of flowering plants (for 1942); Dr. George G. Simpson of the American Museum of Natural History, for his outstanding contributions in the field of vertebrate palæontology, including a study of the Mesozoic mammals, and distinction as a field collector, systematic palrontologist and original thinker on broad problems of evolution (for 1943); Dr. William J. Arkell, formerly of New College, Oxford, now with the Ministry of Transport, for his outstanding contributions to palæontology and geology, including intensive studies of stratigraphic units of different geologic age in widely separate regions, British Jurassic faunas, the history of the region of Great Britain in Jurassic times, palæoecology, the late Neogene history of the Nile region, and other services, all leading to important publications.

Ordnance Distinguished Service Award of the Ordnance Department, United States Army. This was presented to the National Academy of Sciences "in recognition of outstanding and meritorious scientific services, in war and peace, for the development, manufacture and maintenance of Ordnance material". The award was authorized on July 20, 1944, and was presented by Major-General G. M. Barnes, chief of the Research and Development Service Ordnance Department.

\section{Textile Industries at the University of Leeds}

THE steady expansion of the wool textile industry of Great Britain up to 1914 was based on the lead given by early textile inventors, aided by the unique skill acquired by successive generations of craftsmen. A great structure had been erected on a foundation of simple empiricism; but the industrialist was still applying imperfectly understood processes to a material of unknown composition and properties. As the training of textile technologists was in the hands of craftsmen with neither scientific training nor research experience, there could be no hope of breaking the vicious circle of empiricism until seientific workers were persuaded to make a study of textile materials and processes. A first step in this direction was taken by the Department of Textile Industries of the University of Leeds in 1919, when a lecturer in textile chemistry was appointed. From this small beginning it was hoped in time to build up such a body of knowledge that textile technology would be transformed into an applied science. This, in turn, was intended to provide the Department with a staff of technologists having scientific as well as technical qualifications; to create a bond between science and the industry by giving its recruits a combined training in science and technology; and to provide industrial research laboratories with scientific men trained in the methods of research on textile materials and processes.

All these aims have now been achieved, owing to the rapid expansion of the research section of the Department since 1928, when the Worshipful Company of Clothworkers made a grant of $£ 3,000$ a year for research purposes. The grant made it possible to appoint a lecturer (now reader) in textile physics (Dr. W. T. Astbury) and two research assistants, besides providing a number of scholarships and fellowships for research workers drawn from the science departments of the universities. Dr. Astbury's work has since been supported by the Rockefeller Trustees, and that of the Textile Chemistry Section by a number of organizations and firms. Both the Textile Physics and Textile Chemistry Sections have been responsible for important advances in pure and applied science, and, excluding staff, there are now twenty-seven research workers in the Department. Its interests cover the whole field of high polymers, from cellulose and the proteins to plastics and synthetic fibres, from biology to technology. A craft has been carried to the forefront of the applied sciences in a single generation.

Needless to say, such rapid expansion has brought difficulties in its train. In a Department which was originally non-scientific, the difficulty of providing accommodation for research workers was always acute, and is now intensified by the needs of the technological staff. Every spare room has been converted into a laboratory, an army hut has been brought into service, and temporary accommodation has been provided in one of the laboratories of the sister Department of Colour Chemistry and Dyeing. The time has now come to consolidate the position, to collect together scattered groups of research workers and to provide research facilities for the technological staff. Two schemes of reorganization are proposed at a total cost of $£ 22,000$, towards which Messrs. Imperial Chemical Industries, Ltd., Dyestuffs Division, and the Tootal Broadhurst Lee Co., Ltd., have each made donations of $£ 2,500$.

\section{The International Setting of Reconstruction}

UNDER the general title "Looking Forward", the Royal Institute of International Affairs is publishing a series of pamphlets on the international aspects of reconstruation, which are intended to stimulate thought and discussion, and to aim at presenting problems rather than to solve them. In the first of these, "Britain and the World" (Pp. 60. 1s. net), the Hon. H. A. Wyndham gives an outline of reconstruction problems; the general background in Europe and the Middle East, and such factors as freedom of trade and migration in the nineteenth century and up to 1939 are discussed in the first part, and Britain's position in the post-war world is considered in the 